\title{
Ground beetle (Coleoptera: Carabidae) communities on green roofs in Switzerland: synthesis and perspectives
}

\author{
Gaël Pétremand ${ }^{1}$ (D) Yannick Chittaro $^{2} \cdot$ Sonja Braaker $^{3} \cdot$ Stephan Brenneisen $^{4}$. \\ Magdalena Gerner ${ }^{4}$ - Martin K. Obrist ${ }^{3}$ - Sophie Rochefort ${ }^{1}$ - Alexander Szallies ${ }^{4}$. \\ Marco Moretti $^{3}$
}

Published online: 26 August 2017

(C) Springer Science+Business Media, LLC 2017

\begin{abstract}
Green roofs have recently gained recognition for their potential contribution to urban ecosystems by providing, among other services, habitat for plants and animals, and stepping stones for mobile organisms, thereby enhancing permeability among habitat patches across densely built cities. In Switzerland, investigations over the past 20 years on more than one hundred distinct green roofs across six cities have provided an unprecedented dataset on ground beetles, albeit with information that is scattered across unpublished reports and local databases. We present here for the first time a synthesis of the state of knowledge of ground beetle communities from green roofs in Switzerland. We describe 91 ground beetles species $(19,428$ individuals) and highlight patterns of species occurrence and composition across green roofs and cities. Most of the roofs host ground beetle communities dominated by five common mobile species with quite diversified ecological requirements. In
\end{abstract}

Gaël Pétremand

gael.petremand@gmail.com

$\triangle$ Marco Moretti

marco.moretti@wsl.ch

1 Research Institute Earth Nature and Environment, Hepia, University of Applied Sciences and Arts Western Switzerland, Route de Presinge 150, CH-1254 Jussy, Geneva, Switzerland

2 Info Fauna - CSCF, Passage Maximilien-de-Meuron 6, CH-2000 Neuchâtel, Switzerland

3 Biodiversity and Conservation Biology, Swiss Federal Research Institute WSL, Zürcherstrasse 111,

CH-8903 Birmensdorf, Switzerland

4 Institute of Natural Resources Sciences, Zurich University of Applied Sciences ZHAW, Grüental 14, CH-8820 Wädenswil, Switzerland addition, we observed nine species (10\% of all species collected) that are conservation concerns in Switzerland and Central Europe as well as numerous stenotopic species (from grasslands and pioneer vegetation). This indicates that, besides sustaining local populations of common species, green roofs can also offer suitable ecological conditions of high conservation interest. We suggest both improving the design of green roofs (composition and configuration of vegetation, as well as soil depth and substrate composition) to increase their ecological value for species with the most different ecological needs, and to integrate green roofs into urban planning to make them more efficient as biodiversity supports.

Keywords Biodiversity · Urban ecology · Urban green · Vertical green · Endangered species · Carabid beetles · Green infrastructures $\cdot$ Red list species

\section{Introduction}

In the last two decades, implementing green roofs in urban planning and on new flat roof buildings has become an important ecological measure of compensation for loss of urban green. In Switzerland, as one of the leading countries implementing green roofs systematically (Brenneisen 2015), green roofs are mandated by building regulations in most large cities based on the numerous benefits they provide for the building itself (e.g., insulation, water retention, pollution removal) but also for residents (e.g., recreation, aesthetics, life quality), and urban biodiversity (e.g., habitat compensation for plants and animals) (Getter and Rowe 2006; Oberndorfer et al. 2007; Kadas 2010). 
In the 1990s, energy savings and improved storm water retention were the main incentives for creating green roofs. Recently their role in reducing urban heat-island effects and provisioning urban habitats for a specific flora and fauna became additional important drivers for green roof implementation, thus contributing to improved urban biodiversity (Oberndorfer et al. 2007).

Nonetheless, only few studies are known to have addressed arthropod biodiversity issues (e.g., Brenneisen 2003, 2006a/b; Kadas 2006; Colla et al. 2009; MacIvor and Lundholm 2011; Tonietto et al. 2011; Williams et al. 2014). Recent studies have shown that green roofs can also improve connectivity between urban habitats, particularly for mobile arthropods (Braaker et al. 2014, 2017). A recent review has also demonstrated that the height of the roof or the distance to other green areas (Blank et al. 2017) does not influence richness or similarity.

Studies on several arthropod groups such as Arachnidae, Coleoptera (Carabidae, Curculionidae, Staphylinidae, etc.) and Hymenoptera (Apoidea, Vespoidea, Formicoidea, etc.) have additionally revealed the presence of endangered species on green roofs (Brenneisen 2003; Kaupp et al. 2004; Brenneisen 2006a/b; Kadas 2006; Tonietto et al. 2011). Ground beetles have been studied on green roofs in Switzerland (Brenneisen 2003; Kaupp et al. 2004; Braaker et al. 2014; Gerner 2015), in Germany (Klausnitzer et al. 1980; Darius and Drepper 1983; Klausnitzer 1988; Müller 1988; Hirschfelder and Zucchi 1992; Achtel 1995; Mecke 1996) and worldwide (Paill and Holzer 2004; MacIvor and Lundholm 2011; Kadas 2006; Meierhofer 2013). The ground beetle is a widely studied family of beetles because of their sensitivity to environmental changes, such as management and disturbances, which makes them suitable indicators of habitat quality (Rainio and Niemelä 2003). The ecology of many species is relatively well known. They occur in almost all terrestrial environments, are geographically widespread (Lövei and Sunderland 1996; Kotze et al. 2011) and have a particular function in ecologically sustainable farming, as many species are good generalist predators of agricultural pests (Kromp 1999). Considering the increasing losses of dry habitats, such as dry meadows/grasslands or riverbanks following the intensification of landscape use in rural areas during the twentieth century (Lachat 2010), patches of urban areas may become an alternative habitat for some xerophilic species (i.e., species adapted to aridity), especially because urban and agricultural carabid communities seem to share many species (Sattler et al. 2011). In cities, such species can find some particularly dry habitats such as gravel pits, wastelands or road verges. A very rich and diverse carabid community can inhabit urban areas as shown by
Czechowski (1981) in Poland, Hirschfelder and Zucchi (1992) in Germany and Niemelä et al. (2002) and Deichsel (2006) in forested patches in different cities around the world. Urban dry meadows have also been shown to support significant ground beetle diversity in Helsinki, Finland, including some specialised xerophilic and seed-consuming (granivorous) species (Venn et al. 2013). Finally, green roofs with structural diversity in terms of vegetation and substrate may also function as substitutes for brownfield sites considering invertebrates' abundance and diversity (Kadas 2010). A green roof is a specific habitat where surface temperatures will most likely be the same as on ground (soil) sites in hot periods but where the period of completely dry conditions (without water in the soil/substrate) is longer than in ground-level habitats since no capillary water flow from the lower parts of the soil is possible. When the weather is hot $\left(35^{\circ} \mathrm{C}\right.$ air temperature) and the substrate is dry, it can be assumed temperatures of up to $40{ }^{\circ} \mathrm{C}$ (Niachou et al. 2001) or even more (up to $60^{\circ} \mathrm{C}$ on bare ground) at the surface of the roof depending on the surface colour (albedo) and rate of evaporation (Brenneisen 2003).

Recent studies have investigated ground beetles on green roofs in different cities in Switzerland, particularly in Zurich, Luzern, Basel, Winterthur, Aarau and Geneva (Brenneisen 2003; Braaker et al. 2014; Gerner 2015; Pétremand and Rochefort 2016). In this paper, we review the results of these studies and highlight possible patterns of species occurrence and species composition across the different cities by answering the following specific questions: i) Which dominant and subdominant species live on green roofs? ii) Are carabid communities consistent between cities? iii) Do green roofs support species of conservation concern in Switzerland? iv) Which (semi-) natural ecosystem and natural habitat are species of conservation concern sampled on urban green roofs usually associated with?

We expected to find a consistent assemblage of dominant and subdominant eurytopic carabid species across cities because of the harsh thermic and ecologic conditions on green roofs. We also expected some of the species on green roofs in Switzerland to be of conservation interest. These species and other scarce and stenotopic species were expected to be associated with grassland or pioneer vegetation patches.

To address these questions we compare the carabid species collected in Swiss cities during different investigations by the authors of this paper and investigate the occurrence and patterns of the most abundant species. We also highlight the occurrence of rare and endangered species in the communities and discuss the conservation value of green roofs. Finally, we characterise the carabid communities occurring on green roofs based on the habitat and ecological preferences of species and define the 
role of green roofs to provide habitat for a specific fauna.

\section{Methods}

Ground beetles were sampled in six of the largest cities in Switzerland over the past 20 years, i.e., in Basel (1999, 2000, 2001, 2003; 2013 and 2014), in Luzern (2001) in Zurich (2010 and 2014), in Winterthur (2014), in Aarau (2014), and in Geneva (2014 and 2015). All these cities are situated on or near the border of the Swiss Plateau, a biogeographic region situated between the Jura Mountains and the northern slopes of the Swiss Alps (Gonseth et al. 2001; Fig. 1).

A summary of the ground beetle studies conducted on green roofs in Switzerland and sampling details are shown in Table 1. Sampling effort was highly variable between cities with Basel as the most investigated city in terms of roofs, traps and years. The green roofs investigated in these studies differ in structure and vegetation composition, including moss and sedum, herbaceous, grassy and even shrubby green roofs. Most green roofs were considered extensive, being covered by sedums and/or herbaceous vegetation growing on a thin substrate layer usually composed of a high percentage volume of mineral matter such as lava-pumice, sandy gravel or brick fragments, and around 10-20\% organic matter. Some extensive green roofs in Basel contained substrates based on natural soils (Brenneisen 2003). Finally, some green roofs with substrates consisting of more soil-content and intensively managed grassy vegetation (regular mowing) were also investigated (e.g., in Geneva: Pétremand and Rochefort 2016). For the purpose of the present review, we did not consider such differences in the analyses, despite the fact that soil conditions may influence the egg deposition and larval development of some ground beetle species.

All green roofs in the studies in our review were sampled with pitfall traps (Barber 1931), a standardised method suitable to collect ground dwelling arthropods including ground beetles (Greenslade 1964). In Zurich (2010) and in Geneva (2014-2015), non-directional yellow window traps (funnel diameter: $42 \mathrm{~cm}$; window high: $50 \mathrm{~cm}$ ) were also used to collect flying insects (Duelli et al. 1999). Data from both trap types were pooled in these two cities.

Dominant species were defined as those with a relative abundance greater than $5 \%$, subdominant as those with a relative abundance between 2 and 5\% (Tischler 1949). We considered a species as "frequent" in one city if it occurred on more than $25 \%$ of the green roofs investigated.

We defined species as endangered if mentioned in the Swiss Red list (RL) (Marggi 1994; Huber and Marggi 2005; adapted by Luka et al. 2009). Some of these are also specified in the Swiss List of National Priority Species (SLNPS, BAFU 2011).

Species nomenclature follows Löbl and Smetana (2003). Two cryptic species, Harpalus anxius and H. subcylindricus, are considered here as one aggregate species.

Ground beetle communities were characterised based on (i) demographic parameters, such as dominance (dominant and subdominant species) and frequency (on roofs) of the different species within the communities, (ii) degree of threat (based on the RL), and (iii) the ecological
Fig. 1 Localization of the sampled cities (black dots) in Switzerland. Biogeographic regions according to Gonseth et al. (2001) are indicated with numbers $(1=$ Jura, 2 = Plateau, $3=$ Northern foothills of the Alps, $4=$ Western Central Alps, $5=$ Southern foothills of the Alps, $6=$ Easter Central Alps)

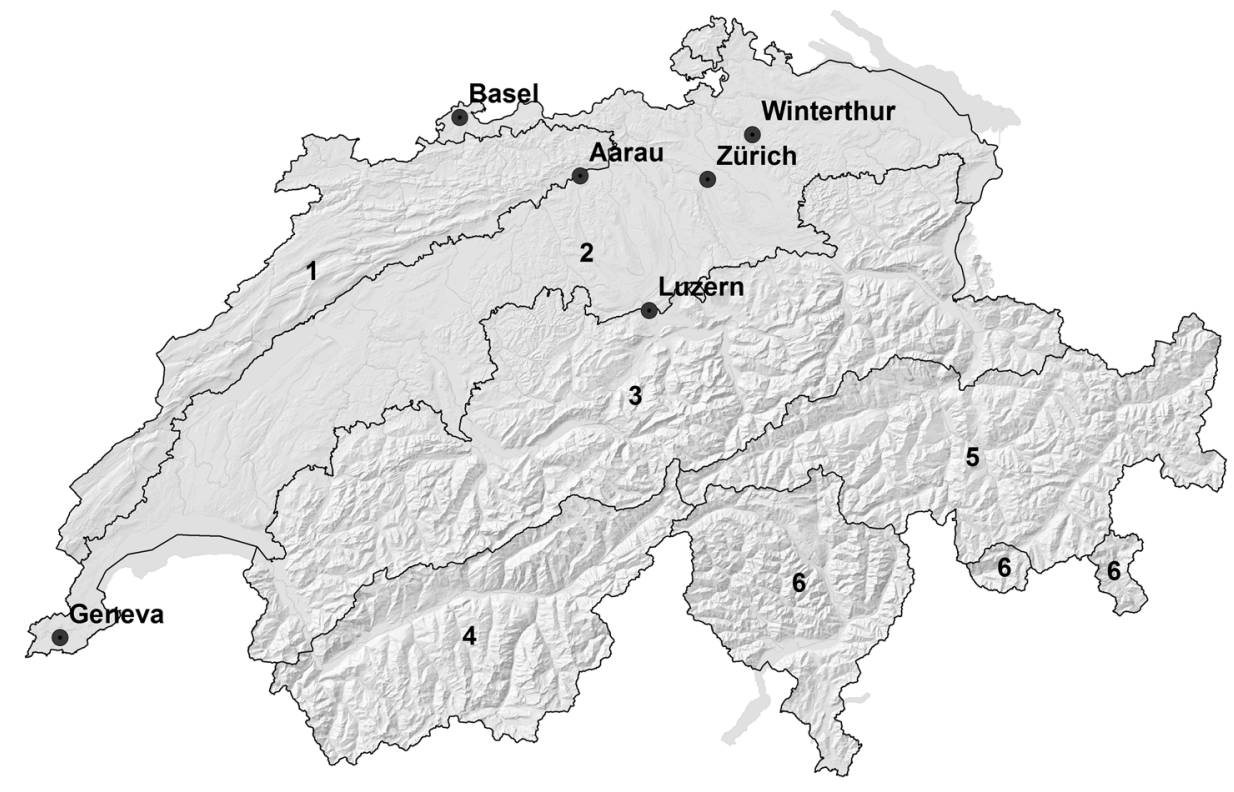


Table 1 Summary of the studies on ground beetle communities occurring on green roofs in six Swiss cities. N. of roofs is the number of green roofs investigated per distinct study within a given sampling period

\begin{tabular}{|c|c|c|c|c|c|c|}
\hline City & $\begin{array}{l}\text { Elevation } \\
\text { (m a.s.1.) }\end{array}$ & N. of roofs & Total N. traps (N. traps/roof) & Sampling period & $\begin{array}{l}\text { N. sampling } \\
\text { weeks }\end{array}$ & References \\
\hline \multirow[t]{2}{*}{ Zurich } & \multirow[t]{2}{*}{408} & 40 & $\begin{array}{c}240 \text { pitfalls }(6)+40 \\
\text { window traps }(1)\end{array}$ & May-Sept 2010 & 10 & Braaker et al. 2014 and Braaker et al. 2017 \\
\hline & & 6 & 120 pitfalls & Apr-Oct 2014 & 28 & Unpublished \\
\hline \multirow[t]{5}{*}{ Basel } & \multirow[t]{5}{*}{244} & 11 & 110 pitfalls $(10)$ & Apr-Nov 1999 & 28 & Kaupp et al. 2004 \\
\hline & & 4 & 40 pitfalls (10) & May-July 2000-2001 & 12 & Brenneisen 2003 \\
\hline & & 6 & 60 pitfalls & Apr-Oct 2003 & 28 & Brenneisen and Hänggi 2006 \\
\hline & & 16 & 280 pitfalls (10-30) & Apr-Oct 2013 & 28 & Gerner 2015 \\
\hline & & 20 & 360 pitfalls (10-30) & Apr-Oct 2014 & 28 & Gerner 2015 \\
\hline \multirow[t]{4}{*}{ Geneva } & \multirow[t]{4}{*}{374} & \multirow[t]{4}{*}{30} & 122 pitfalls (3-6) & Apr-June 2014 Apr- & 3 & \multirow[t]{4}{*}{ Pétremand and Rochefort 2016} \\
\hline & & & 122 pitfalls (3-6) & June 2015 & 3 & \\
\hline & & & 122 pitfalls (3-6) & Aug-Sep 2014 & 3 & \\
\hline & & & 10 window traps $(1)$ & Apr-June 2015 & 7 & \\
\hline Winterthur & 439 & 2 & 70 pitfalls $(20-50)$ & Apr-Oct 2014 & 28 & Unpublished \\
\hline Aarau & 381 & 1 & 30 pitfalls (30) & Apr-Oct 2014 & 28 & Unpublished \\
\hline Luzern & 437 & 7 & 70 pitfalls (10) & Apr-Oct 2001 & 26 & Brenneisen 2003 \\
\hline
\end{tabular}

and functional traits of the species. Functional traits included habitat affinity (hygrohil = humid habitat dweller vs. xerophil = dry habitat dweller), habitat tolerance (stenotopic $=$ tolerating only a narrow range of environmental conditions vs. eurytopic $=$ tolerating a broad range of environmental conditions), and wing morphology (brachypterous = short wings or wingless vs. macropterous $=$ long wings vs. dimorphic $=$ long or short wings depending on the environmental conditions and population parameters) as a proxy of flight ability (non-flying vs. flying species, respectively; Kromp 1999). Trait values were extracted from Luka et al. (2009) and Homburg et al. (2014).

\section{Results}

Our review of faunistic investigations conducted on green roofs in six Swiss cities over the past 20 years covers 19,428 sampled ground beetles belonging to 91 species. Overall, these communities consisted of $78 \%$ macropterous and $22 \%$ dimorphic species, while none were brachypterous (Appendix). Concerning habitat affinity, about $35 \%$ of the sampled species were xerophilic, $21 \%$ hygrophilic and $44 \%$ mesophilic. Regarding habitat tolerance, $31 \%$ were stenotopic and $69 \%$ eurytopic.

\section{Dominant and frequent species on green roofs in Switzerland}

Table 2 shows the 21 most common ground beetle species, which were sampled on green roofs of at least four out of the six investigated cities. Six of these were collected in all cities (in bold) and were mainly dominant: Bembidion quadrimaculatum, Tachyura parvula, Amara aenea, Harpalus affinis, Harpalus rubripes and Anisodactylus binotatus.

Overall the most dominant species are eurytopic and either xerophilic or mesophilic (Luka et al. 2009). For example, B. quadrimaculatum and A. aenea are two highly abundant xerophilic species that are usually found in pioneer vegetation, grassland or crops (Luka et al. 2009). Only one very abundant species is stenotopic, H. affinis, and it is only associated with pioneer vegetation (Luka et al. 2009). The only hygrophilic species, Tachyura quadrisignata, is usually associated with riverbanks and wetlands.

All species that were found on at least $25 \%$ of the roofs sampled in the three main cities (where at least ten green roofs were investigated) are given in Table 3 . The first five species listed were highly frequent on the green roofs of the three main cities. Most of these were xerophilic and eurytopic. All were also found in each of the six cities (Table 2, top rows). A few species differ considerably in frequency between cities: Pterostichus vernalis, Anisodactylus binotatus, Bembidion properans, Microlestes minutulus and Amara tibialis.

Of the species listed in Table 3, six are missing in Table 2. While three of these (Harpalus anxius/subcylindricus, Tachyura sexstriata and Parophonus maculicornis) were present in only two or three cities, they were sometimes frequent within one or several cities. All of these are stenotopic species (Table 4), and may be more present regionally or were unfortunately not caught on the green roofs sampled. The three other species (Amara tibialis, Harpalus attenuatus, 
Table 2 Relative abundance (\%) of the most common ground beetle species found in at least four of the six Swiss cities investigated in the past 20 years $(\mathrm{BS}=\mathrm{Basel}, \mathrm{LU}=$ Luzern, $\mathrm{ZH}=$ Zurich, $\mathrm{AR}=$ Aarau, $\mathrm{WI}=$ Winterthur, GE = Geneva). Species labelled in bold were sampled in all six cities, i.e., Freq. (frequency) $=6$. Bold abundance percentages indicate that a species is dominant in a city $(\geq 5 \%)$.

When the same city was sampled over several years, the number of individuals is accumulative across all years. Habitat tolerance (Luka et al. 2009): $\mathrm{E}=$ eurytop;

$\mathrm{S}=$ stenotop. Habitat affinity (Luka et al. 2009): $\mathrm{H}=$ hygrophil; $\mathrm{M}=$ mesophil; $\mathrm{X}=$ xerophil
Table 3 List of species and the percentage of roofs on which frequent ground beetles occurred on at least $25 \%$ of the 102 green roofs investigated in the three main Swiss cities. $\mathrm{n}=$ number of roofs sampled. $+=$ species occurs on $<25 \%$ of investigated green roofs; $-=$ species was not found)

\begin{tabular}{|c|c|c|c|c|c|c|c|c|c|}
\hline \multirow[t]{2}{*}{ Species names } & \multicolumn{6}{|c|}{ Relative abundance (\%) } & \multirow[t]{2}{*}{ Freq. } & \multirow{2}{*}{$\begin{array}{l}\text { Habitat } \\
\text { tolerance }\end{array}$} & \multirow{2}{*}{$\begin{array}{l}\text { Habitat } \\
\text { affinity }\end{array}$} \\
\hline & $\mathrm{BS}$ & LU & $\mathrm{ZH}$ & $\mathrm{AR}$ & WI & GE & & & \\
\hline $\begin{array}{l}\text { Bembidion } \\
\quad \text { quadrimaculatum }\end{array}$ & 6.6 & 12.2 & 9.9 & 66.8 & 62.7 & 2.6 & 6 & $\mathrm{E}$ & $\mathrm{X}$ \\
\hline Tachyura parvula & 13.5 & 30.2 & 7.9 & 0.6 & 0.4 & 14.1 & 6 & $\mathrm{E}$ & $\mathrm{X}$ \\
\hline Amara aenea & 12.0 & 0.4 & 19.3 & 0.6 & 1.5 & 12.2 & 6 & $\mathrm{E}$ & $\mathrm{X}$ \\
\hline Harpalus affinis & 16.6 & 1.3 & 4.2 & 3.7 & 9.4 & 10.4 & 6 & $\mathrm{~S}$ & M \\
\hline Harpalus rubripes & 13.5 & 21.3 & 15.3 & 0.8 & 1.5 & 9.9 & 6 & $\mathrm{E}$ & M \\
\hline Anisodactylus binotatus & 1.7 & 2.2 & 6.9 & 1.0 & 0.6 & 0.3 & 6 & $\mathrm{E}$ & M \\
\hline Pterostichus vernalis & 0.9 & 5.0 & 16.5 & 0.2 & & 0.5 & 5 & $\mathrm{E}$ & M \\
\hline Tachyura quadrisignata & 5.0 & 3.5 & 3.1 & 0.4 & 0.3 & & 5 & $\mathrm{~S}$ & $\mathrm{H}$ \\
\hline Bembidion lampros & 0.2 & & 0.6 & 3.5 & 6.3 & 0.1 & 5 & $\mathrm{E}$ & M \\
\hline Tachys bistriatus & 0.3 & & 0.1 & 3.7 & 5.9 & 0.4 & 5 & $\mathrm{E}$ & M \\
\hline Harpalus rufipes & 0.4 & & 0.4 & 3.9 & 4.9 & 2.3 & 5 & $\mathrm{E}$ & M \\
\hline Microlestes minutulus & 3.1 & & 0.0 & 0.6 & 0.2 & 3.8 & 5 & $\mathrm{E}$ & $\mathrm{X}$ \\
\hline Harpalus griseus & 0.3 & & 0.1 & 3.7 & 1.9 & 0.2 & 5 & $\mathrm{E}$ & $X$ \\
\hline Trechus quadristriatus & 0.3 & & 0.1 & 1.2 & 0.4 & 0.1 & 5 & $\mathrm{~S}$ & M \\
\hline Agonum muelleri & 0.0 & 0.2 & 0.9 & 3.5 & & 0.9 & 5 & $\mathrm{E}$ & M \\
\hline Stenolophus teutonus & 0.4 & 0.2 & 1.3 & & 0.2 & 0.4 & 5 & $\mathrm{~S}$ & M \\
\hline Bembidion properans & 1.0 & 13.0 & 7.6 & & & 6.1 & 4 & $\mathrm{E}$ & M \\
\hline Acupalpus meridianus & 0.1 & 9.1 & 0.1 & 0.2 & & & 4 & $\mathrm{E}$ & M \\
\hline Lionychus quadrillum & 0.7 & & 0.1 & 1.0 & 0.2 & & 4 & $\mathrm{E}$ & $\mathrm{X}$ \\
\hline Ophonus azureus & 0.3 & & 0.1 & & 0.2 & 0.6 & 4 & $\mathrm{~S}$ & $X$ \\
\hline
\end{tabular}

\begin{tabular}{llll}
\hline Species names & $\begin{array}{l}\text { Zurich 2010 } \\
n=40\end{array}$ & $\begin{array}{l}\text { Basel 2013-2014 } \\
n=32\end{array}$ & $\begin{array}{l}\text { Geneva 2014-2015 } \\
n=30\end{array}$ \\
\hline Tachyura parvula & $83 \%$ & $67 \%$ & $88 \%$ \\
Harpalus rubripes & $70 \%$ & $72 \%$ & $59 \%$ \\
Amara aenea & $63 \%$ & $66 \%$ & $55 \%$ \\
Bembidion quadrimaculatum & $63 \%$ & $58 \%$ & $40 \%$ \\
Harpalus affinis & $30 \%$ & $72 \%$ & $40 \%$ \\
Pterostichus vernalis & $60 \%$ & $34 \%$ & + \\
Anisodactylus binotatus & $58 \%$ & $44 \%$ & + \\
Harpalus rufipes & $25 \%$ & + & $26 \%$ \\
Parophonus maculicornis & $28 \%$ & + & $26 \%$ \\
Stenolophus teutonus & $50 \%$ & + & + \\
Trechus quadrisignatus & + & $25 \%$ & + \\
Bembidion properans & $48 \%$ & - & $55 \%$ \\
Harpalus anxius/subcylindricus & - & $33 \%$ & $29 \%$ \\
Microlestes minutulus & - & $28 \%$ & $51 \%$ \\
Tachyura quadrisignata & $35 \%$ & + & - \\
Tachyura sexstriata & - & + & $29 \%$ \\
Amara tibialis & - & $66 \%$ & - \\
Harpalus attenuatus & - & $30 \%$ & - \\
Syntomus foveatus & - & $27 \%$ & - \\
\hline & & &
\end{tabular}


Table 4 Stenotopic ground beetle species sampled on green roofs in at least two out of six investigated cities in Switzerland $(\mathrm{BS}=$ Basel, $\mathrm{LU}=$ Luzern, $\mathrm{ZH}=$ Zurich, $\mathrm{AR}=$ Aarau, $\mathrm{WI}=$ Winterthur, GE $=$ Geneva). The number of individuals sampled in each city as well as species-specific characteristics based on Luka et al. (2009) are given, i.e., habitat preference $(\mathrm{GL}=$ grassland, $\mathrm{PV}=$ pioneer vegetation, $\mathrm{RW}=$ riverbank and wetland, FD = field) and habitat affinity (SH = steno-hygrophil; $\mathrm{H}=$ hygrophil; $\mathrm{M}=$ mesophil; $\mathrm{X}=$ xerophill); RL (Red List) status in Switzerland $(\mathrm{R}=$ very rare species, $1=$ nearly extinct)

\begin{tabular}{|c|c|c|c|c|c|c|c|c|c|}
\hline Species names & $\begin{array}{l}\mathrm{RL} \\
\text { status }\end{array}$ & $\begin{array}{l}\text { Habitat } \\
\text { preference }\end{array}$ & $\begin{array}{l}\text { Habitat } \\
\text { affinity }\end{array}$ & $\mathrm{BS}$ & LU & $\mathrm{AR}$ & WI & GE & $\mathrm{ZH}$ \\
\hline Amara fulvipes & $\mathrm{R}$ & GL & $\mathrm{X}$ & 3 & & & & 14 & 1 \\
\hline Amara lucida & & GL & M & & & & & 3 & 1 \\
\hline Amara similata & & PV & M & 3 & & & 1 & & \\
\hline Amara tibialis & 1 & GL & $\mathrm{X}$ & 385 & & 2 & & & \\
\hline Bembidion femoratum & & RW & $\mathrm{H}$ & 3 & & & 3 & & 17 \\
\hline Harpalus affinis & & PV & M & 2019 & 6 & 18 & 64 & 196 & 165 \\
\hline $\begin{array}{l}\text { Harpalus } \\
\quad \text { anxius/subcylindricus }\end{array}$ & & GL & $\mathrm{X}$ & 474 & & & & 337 & \\
\hline Harpalus attenuatus & $\mathrm{R}$ & PV & $\mathrm{SH}$ & 215 & & 6 & & & \\
\hline Harpalus distinguendus & & PV & $\mathrm{X}$ & 117 & & & & 1 & 7 \\
\hline Ophonus azureus & & PV & $\mathrm{X}$ & 55 & & & 1 & 12 & 4 \\
\hline Ophonus puncticeps & & PV & $\mathrm{X}$ & 1 & & & & & 3 \\
\hline Parophonus maculicornis & & GL & M & 172 & & & & 7 & 33 \\
\hline Poecilus versicolor & & GL & M & 20 & 1 & & & & \\
\hline Stenolophus teutonus & & PV & M & 43 & 1 & & 1 & 7 & 52 \\
\hline Tachyura quadrisignata & & RW & $\mathrm{H}$ & 598 & 16 & 2 & 2 & & 124 \\
\hline Tachyura sexstriata & & RW & $\mathrm{H}$ & 456 & 2 & & & 145 & \\
\hline Trechus quadristriatus & & FD & M & 37 & & 6 & 3 & 1 & 3 \\
\hline
\end{tabular}

Syntomus foveatus) were frequent in Basel but were not sampled at all in Zurich and Geneva. This can be explained, at least partially, by the restricted biogeographical distribution of the populations (as it is the case for A. tibialis).

\section{Stenotopic species on green roofs}

Table 4 shows the 17 stenotopic ground beetle species found on green roofs in at least two out of the six investigated cities. Most of these are either xerophilous or mesophilic and prefer grassland habitats and pioneer vegetation. Only three species are hygrophil, and one of these, Trechus quadristriatus, is associated with agricultural fields. Almost all these species were collected on green roofs in Basel, the city investigated most intensively (Table 1).

\section{Endangered ground beetle species on green roofs}

Among the 91 ground beetle species collected, four were of particular conservation interest, i.e., Amara tibialis, Bembidion atrocaeruleum (Fig. 2), Bembidion prasinum and Panagaeus bipustulatus (Fig. 2). These species are listed on the Red List (RL) of endangered species in Switzerland (Luka et al. 2009) and on the Swiss List of National Priority Species (SLNPS) (BAFU 2011) (see Appendix). Although they are not currently threatened, Amara cursitans, Amara fulvipes (Fig. 2), Amara kulti, Harpalus attenuatus (Fig. 2) and Harpalus progrediens are considered as "very rare species" (R) in Switzerland and are therefore of particular interest as well.
Fig. 2 Some of the rare and endangered species collected on green roofs in Switzerland. From the left: Bembidion atrocaeruleum (a), Panagaeus bipustulatus (b), Harpalus attenuates (c) and Amara fulvipes (d) (Photos: Andreas Sanchez)

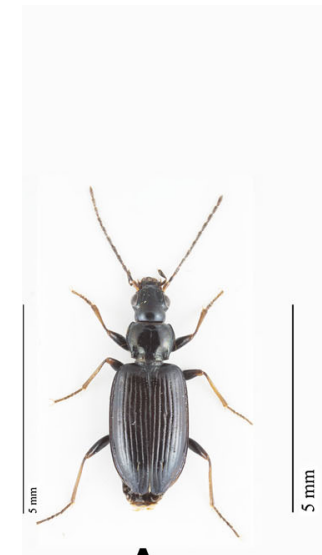

A

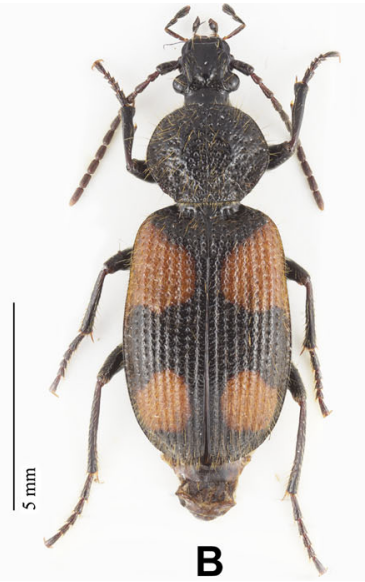

B
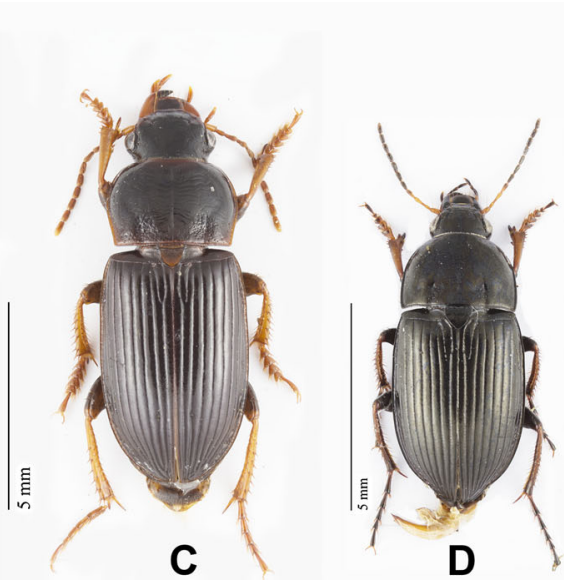


\section{Discussion}

Ground beetles are well represented on green roofs in Switzerland with 91 out of the 532 species (17\%) known to Switzerland (Luka et al. 2009; Chittaro and Marggi 2016) being recorded on the green roofs in the present study. Eleven ground beetle species (ca. 10\% of the species sampled) are either endangered or very rare in Switzerland. This shows, especially for carabids, that green roofs may provide an interesting habitat for many species and thus should be taken into consideration by urban planners. Brenneisen (2003) and Gonsalves (2016) showed higher numbers of red listed beetle species on green roofs with higher structural vegetation diversity (i.e., moss, sedum, herbaceous, shrubby layers) and those with higher substrate thickness. Nevertheless, due to very high variability in the conditions on green roofs and in the vicinity, their benefit from a conservation perspective is not necessarily guaranteed.

The ecological characteristics of the species show that green roofs support a specific ground beetle community composed of one third stenotopic species. For more than one third, a xerophilic trend is visible. Given that only winged individuals seem to access green roofs, short-winged species are either unable to colonize green roofs or are filtered out by isolation. While it cannot be ruled out that eggs or larvae are brought in with roof soil at the time of green roof construction, flight ability seems to be the main filter for viable populations of ground beetles on green roofs.

\section{Common ground beetles species}

The five most frequent and dominant ground beetle species on the sampled green roofs (i.e., Amara aenea, Bembidion quadrimaculatum, Harpalus affinis, Harpalus rubripes, and Tachyura parvula) mainly structure the ground beetle communities living on green roofs in Switzerland. Previous work has shown that these species have been found in all developmental stages (adult, immature and/or larvae) on green roofs, suggesting that they reproduce and maintain populations on roofs (Kaupp et al. 2004). These species can also be expected to be frequent on green roofs in other cities in northern and central Europe. With the exception of T. parvula, they have also been found on green roofs in London (Kadas 2006), in Germany (Müller 1988; see Kaupp et al. 2004) and H. affinis specifically, also in Canada (MacIvor and Lundholm 2011). The other 15 species listed in Table 2 can be considered as part of a more general assemblage of species common on green roofs across Switzerland. Thus, their presence does not indicate a special quality of a particular green roof, but attests to green roof minimal habitat conditions required for common species to exist. Some of these 15 more general species have also been collected at larval or immature stages in Basel, namely, Acupalpus meridianus, Anisotactylus binotatus, Bembidion properans, Tachyura quadrisignata, Lionychus quadrillum and Pterostichus vernalis (Kaupp et al. 2004). Some of these (A. binotatus and P. vernalis) and others (Microlestes minutulus and Trechus quadristriatus) have also been found in several cities throughout Germany (Müller 1988; see Kaupp et al. 2004).

Our results on the distribution and frequency of the dominant species among the six investigated cities (Tables 2 and 3 ) suggest that some species have a highly variable distribution on green roofs across cities. This can be explained in some cases by a restricted distribution in Switzerland (e.g. A. tibialis), but in other cases, causes that are difficult to identify may contribute, such as habitat heterogeneity within green roofs, the surrounding environment (parks, trees, etc.), the adaptation of local populations to human infrastructures, and the origin of the soil on the green roof. All these factors may lead to the highly variable distribution of some sampled species across cities.

\section{Stenotopic species on green roofs}

The presence of stenotopic species substantiates the restricted ecological conditions encountered on green roofs (e.g., high temperatures, strong winds and low vegetation cover). Some species with only a small number of individuals collected in this study may also have been caught during dispersal and consequently could not establish themselves and reproduce on green roofs. The presence of some hygrophilic species suggests that some green roofs may have water drainage problems causing partly wet conditions. The stenotopic species found prefer mostly grassland and pioneer vegetation (Table 4, Appendix). Green roofs thus provide an environment that not only has grassland habitat characteristics but also those of pioneer vegetation. Accordingly, depending on their management type (intensive or extensive) and vegetation composition (sedums, herbaceous, grassy and even shrubby), green roofs can represent a habitat for numerous stenotopic and scarce species (see 4.1) in the urban ecosystem as already shown by several studies on various other taxonomic groups (Brenneisen 2003; Brenneisen and Hänggi 2006; Kaupp et al. 2004; Kadas 2006; Colla et al. 2009; MacIvor and Lundholm 2011).

\section{Conservation interest of green roofs for ground beetles}

Amara tibialis is a highly endangered species (RL: 1) in Switzerland with a high conservation priority (SLNPS: 2). 
This species is known in fewer than ten localities in Switzerland (CSCF database), mostly located around Basel. According to Luka et al. (2009), this xerophilic and stenotopic species occurs in dry and nutrient-poor grassland. It prefers sunny locations with dry grass-covered ground. The large number of specimens collected shows that green roofs in the Basel region are very valuable habitats for this species. Its larvae have been found on green roofs in Basel, suggesting that it is a permanent inhabitant (Kaupp et al. 2004).

Panagaeus bipustulatus is also a threatened species (RL: 3 ) in Switzerland. This xerophilic and stenotopic species lives in dry, gravelly sand, on xerothermic slopes and in ruderal habitats (Luka et al. 2009), often in very restricted areas (Marggi 1992). Green roofs appear to satisfy its environmental requirements but only four individuals were found on two green roofs (in Basel and Aarau), implying that these records are occasional, not necessarily affirming a permanent colonization. Amara cursitans, Amara fulvipes and Amara kulti also favour dry ruderal habitats (Luka et al. 2009) and find comparable ecological conditions on green roofs. Green roofs also provide a suitable habitat for Harpalus attenuatus (215 individuals collected in Basel and 6 in Aarau), which was previously only known in about ten Swiss locations (all situated in the $100-200 \mathrm{~km}$ distant cantons of Valais and Geneva). This species had never been found before in Northern Switzerland, even though it has been identified in Southern Germany (Trautner 1994) and Alsace (Callot 2016). Its occurrence hints towards green roofs as valuable in the conservation of this species.

Fifty-two specimens of Harpalus progrediens were collected on green roofs in Basel. This species is known to be hygrophilic and to occur on vegetated riverbanks and riparian forests (Luka et al. 2009). Its presence on green roofs might be due to the fact that some green roofs provide wet conditions during some periods of the year depending on the drainage situation. Two additional riparian species listed on RL and SLNPS were also collected on green roofs in Winterthur: Bembidion atrocaeruleum and Bembidion prasinum. Since, in these cases, only a single specimen each was collected, they can be considered as vagrant individuals on green roofs. Thus, green roofs are likely of lesser conservation value for these species.

\section{Application and guideline issues}

The specific habitat conditions (e.g., soil quality, drainage conditions) that support the successful and longlasting colonisation of green roofs by ground beetles is a topic of great importance for future research in order to facilitate the detailed planning of targeted habitat compensation with such roofs. While our analyses indicate that green roofs appear to provide suitable conditions for some species of conservation interest, the relevant factors involved have not been clearly identified to date.

The results show that, compared to other cities, a remarkable number of stenotopic and rare species of conservation interest have been recorded on green roofs in Basel. This city regulates substrate composition by means of mandatory guidelines. Green roof substrates must contain sandy gravel and additional organic as well as mineral material. These guidelines are based on the initial findings of Brenneisen (2003) and Brenneisen and Hänggi (2006) that demonstrated that species living naturally on riverbanks benefit from green roofs. Consequently, the substrate composition for extensive green roofs should be natural soil-based or closely mimic such habitat conditions by being composed principally of sandy gravel.

Another important factor supporting biodiversity and conservation aspects may be that green roof guidelines in Basel mandate a diverse setup of roof substrates with thicknesses of 8,12 and $15 \mathrm{~cm}$, dividing the surface into different habitat conditions and vegetation structures (Fig. 3). In any case, to fully account for the high richness of valuable species in Basel, further research is needed to disentangle the combined effects of the biogeographically particular location of Basel, the rich ground beetle community on the surrounding green roofs, the role of the city's guidelines, and, possibly most importantly, the relatively high sampling effort compared to other cities (for example, the number of years, or the number of traps/roof).

\section{Conclusion}

This analysis provides a list of common ground beetle species occurring on green roofs in Switzerland, as well as a list of uncommon stenotopic species. In Switzerland, green roofs appear to have a high conservation interest for several species of ground beetles on which they find suitable ecological conditions for their development. For this reason, and also because they improve the connectivity of habitats in urban ecosystems, this beetle family should be considered in further studies on biodiversity on green roofs. In addition, the rather diverse ecological requirements of the carabid community investigated 
Fig. 3 Green roof of the University Hospital Basel, Klinikum 2. The pictures show the different substrate types used, such as sandy, slightly-loamy gravel and top soil in different thicknesses $(8,15$ and $20 \mathrm{~cm})$, in line with mandatory guidelines for the city of Basel. The picture on the left was taken just after installation in 2003 and on the right after three vegetation periods in June 2006. This green roof had very high carabid species richness ( $>20$ species), most likely occurring because of the variation of microhabitats and the use of natural soil
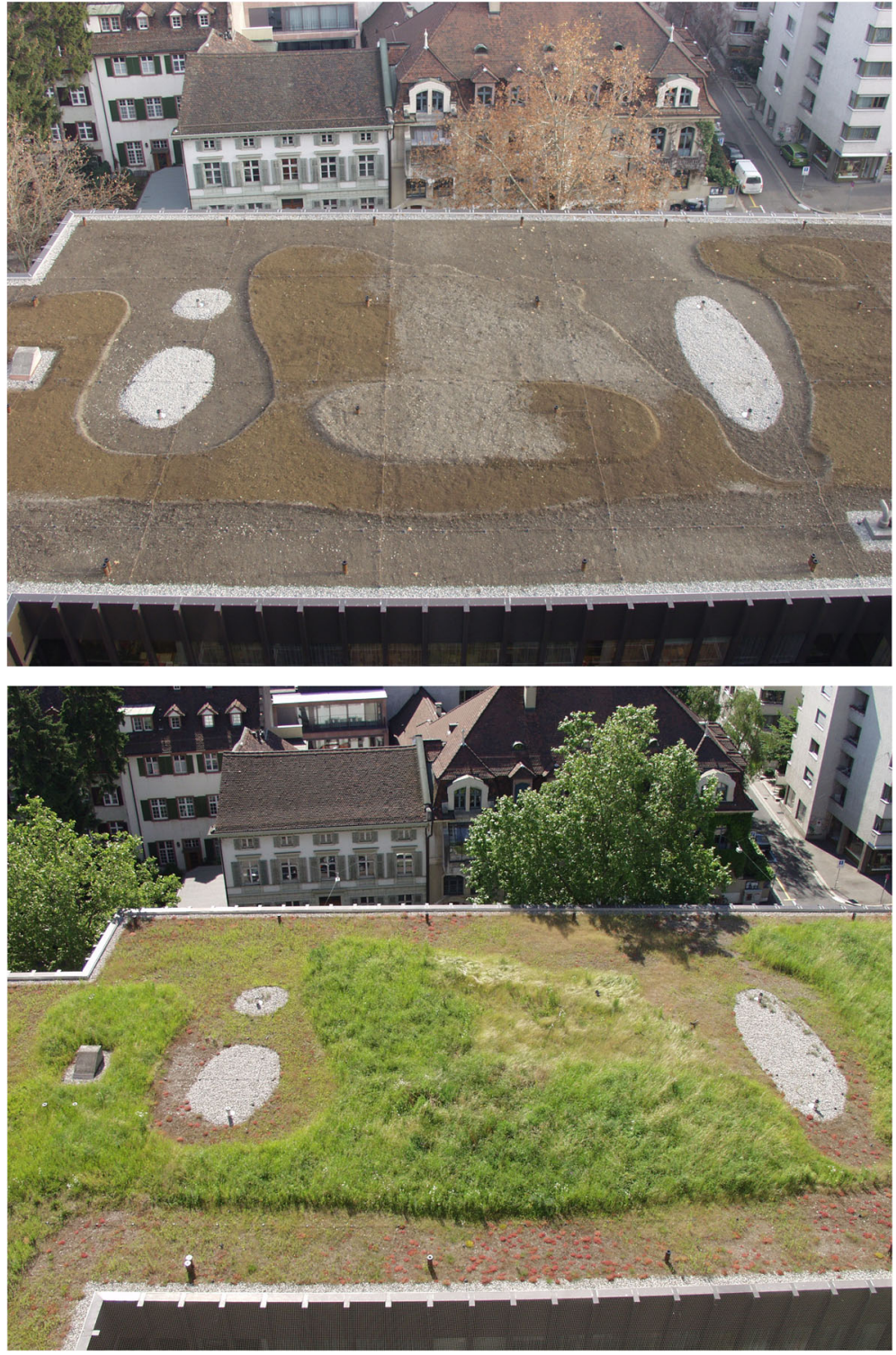

emphasize the value of green roofs for their diversity in terms of vegetation, substrate composition and structure. Finally, this study identifies two characterization criteria that may be used in the evaluation of roofs, with no particular priority between the two: i) roofs with dominant and frequent species that are important to maintain viable and functional populations/communities in densely urbanised areas (which may be due to suitable local habitat conditions but also well-connected urban landscape surroundings); ii) roofs with rare, endangered and stenotopic species that contribute in a particular way to the meta-population dynamics of such species.

The surveys reviewed here show that a high number of green roofs in Switzerland may be suitable for only common species. They might be improved towards sustaining more species, and especially those of conservation concern, by slightly increasing the substrate thickness and/or locally varying the substrate compositions.

Acknowledgments We would like to thank Werner Marggi $(\mathrm{CH}-$ Thun) for the verification of some difficult identifications of ground beetles, Andrea Sanchez (info fauna - CSCF) for providing the ground beetles' photographs and Michel Sartori (Museum of Zoology, Lausanne) for making the photographic equipment available. We are also very grateful to the canton of Geneva (DGAN, OCEN, DGEau) and HES-SO for funding support for the Geneva surveys, all partners that financed the studies considered in this paper and finally, to all those that helped with the field surveys. 


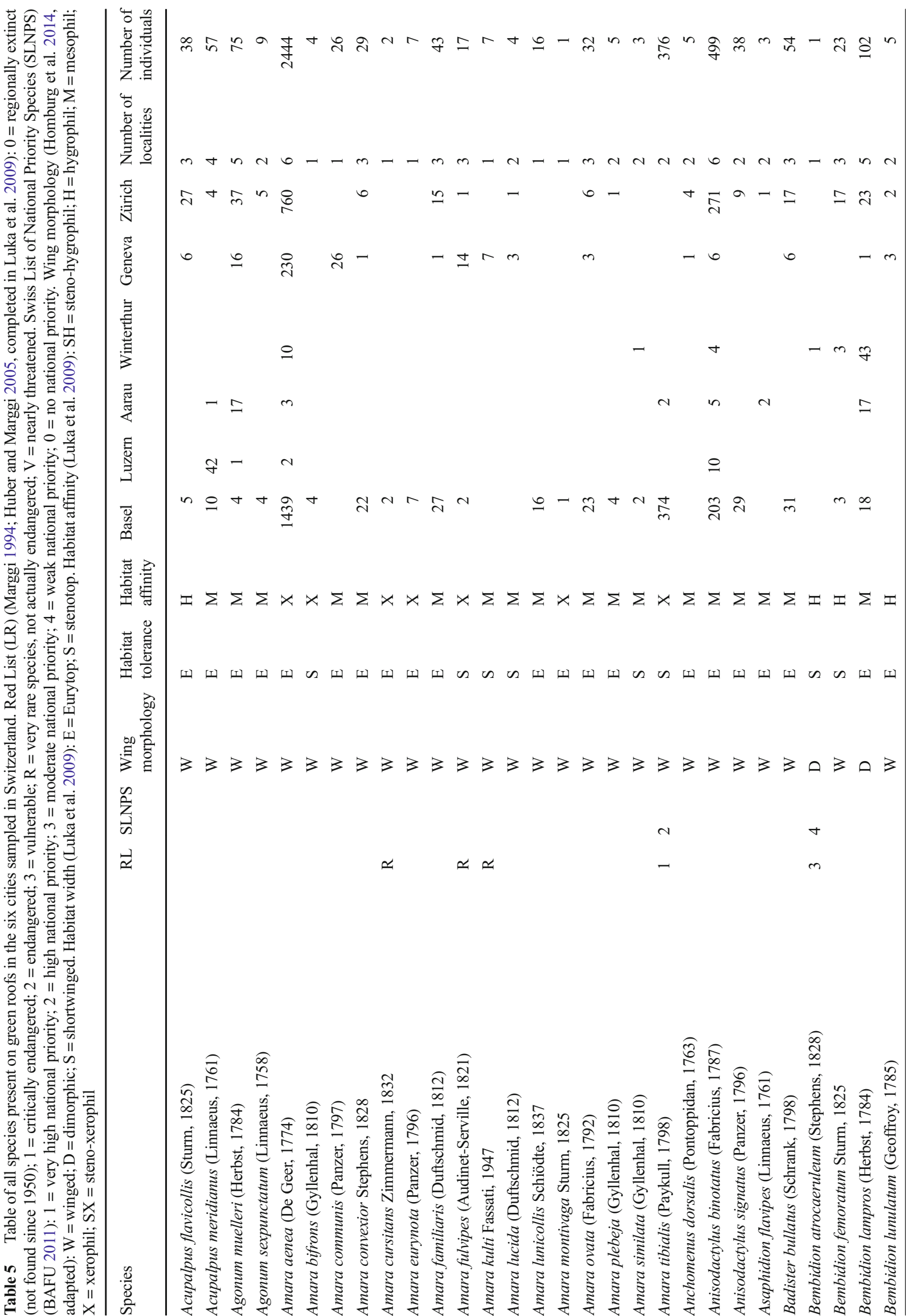




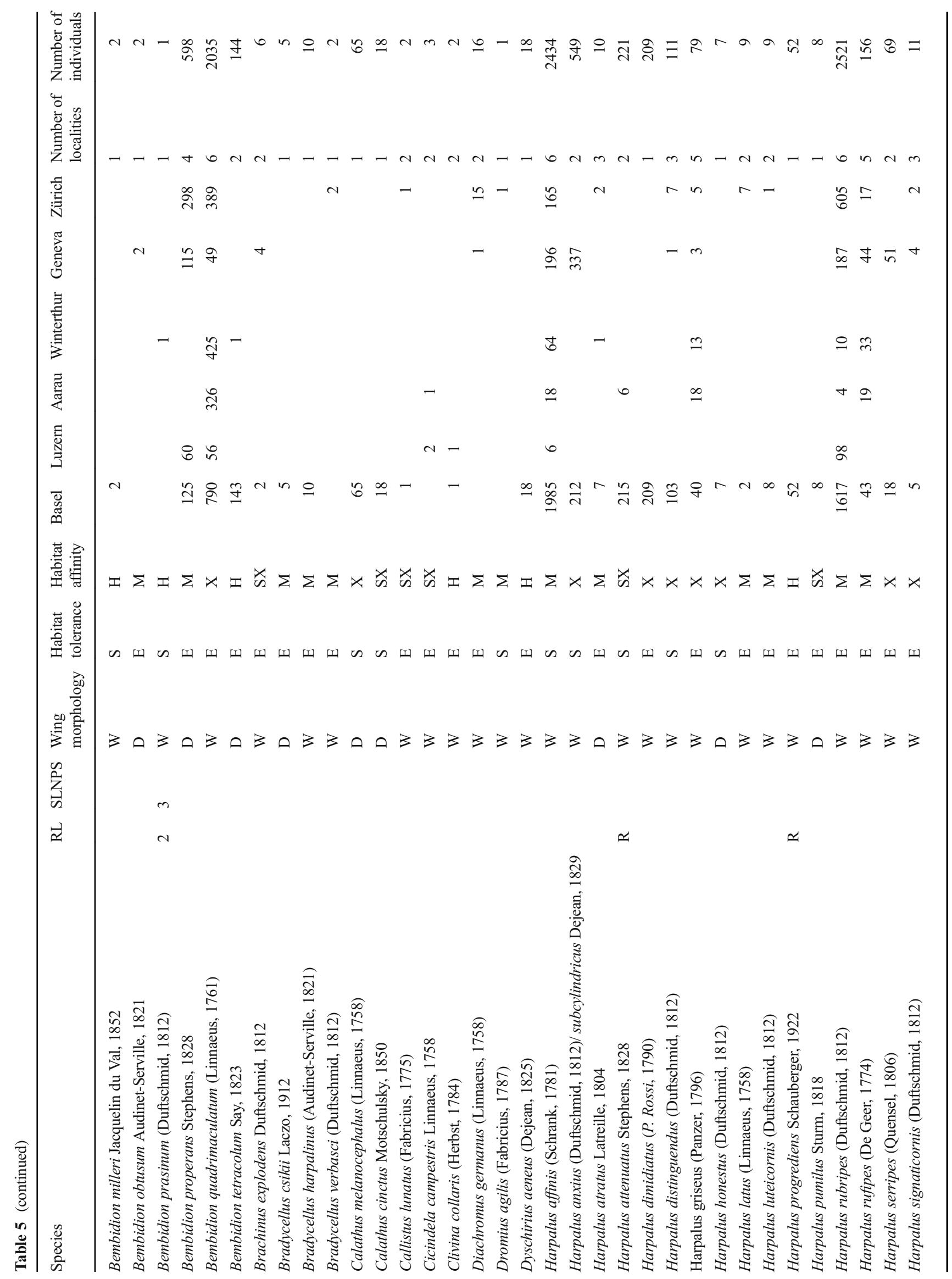




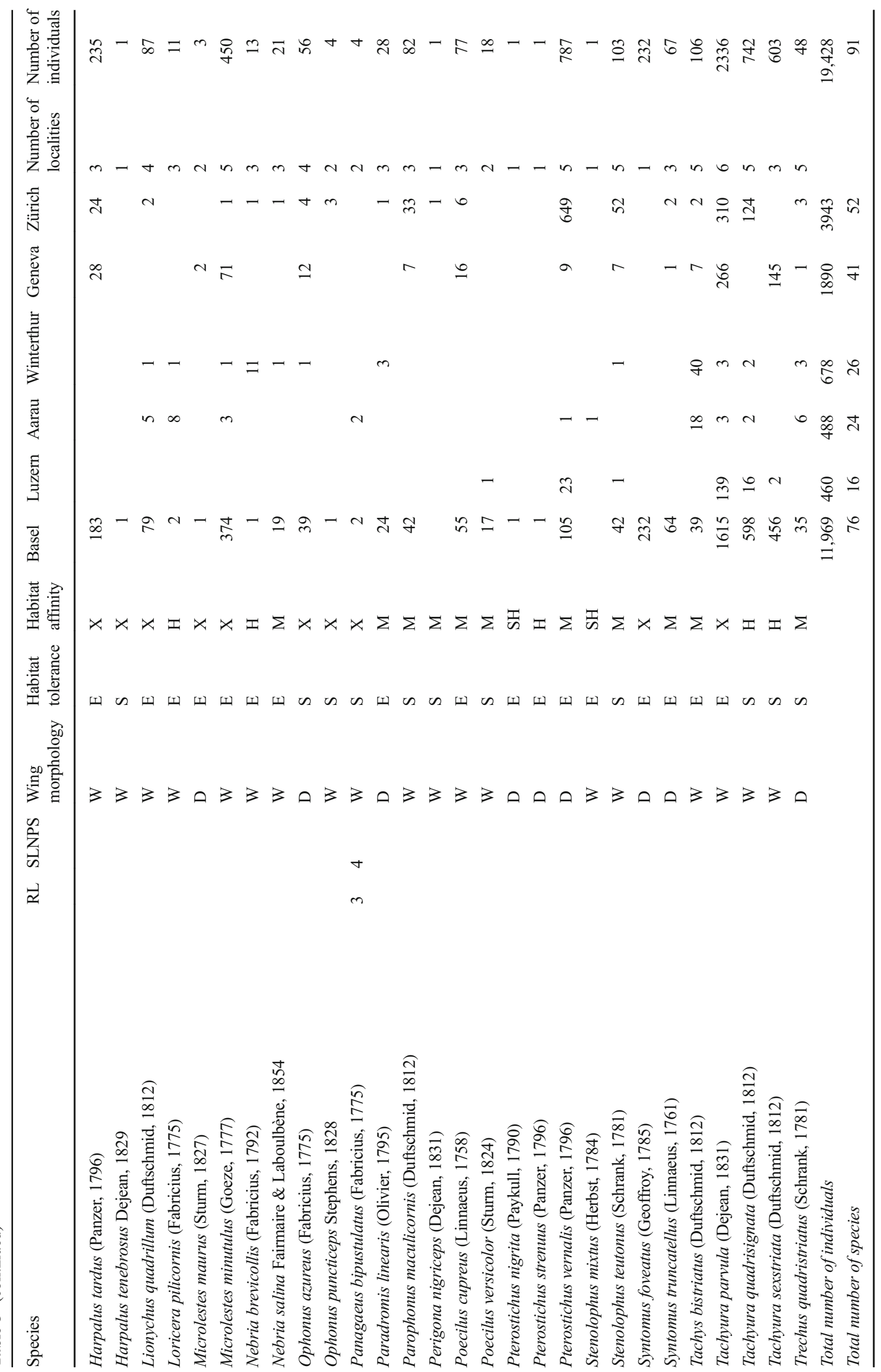




\section{References}

Achtel L (1995) Untersuchungen zur Besiedlung begruenter Daecher durch Arthropoda im Stadtbereich. Oekol Mitt Suppl 19:7-25

BAFU (2011) Liste der National Prioritären Arten. Arten mit nationaler Priorität für die Erhaltung und Förderung, Stand 2010. Bundesamt für Umwelt, Bern Umwelt-Vollzug Nr 1103

Barber HS (1931) Traps for cave-inhabiting insects. Journal of Elisha Mitchell Scientific Society 46:259-266

Blank L, Vasl A, Schindler BY, Kadas GJ, Blaustein L (2017) Horizontal and vertical island biogeography of arthropods on green roofs: a review. Urban Ecosyst. https://doi.org/10.1007/s11252-016-0639-9

Braaker S, Ghazoul J, Obrist MK, Moretti M (2014) Habitat connectivity shapes urban arthropod communities: the key role of green roofs. Ecology 95:1010-1021

Braaker S, Obrist KM, Ghazoul J, Moretti M (2017) Habitat connectivity and local conditions shape taxonomic and functional diversity of arthropods on green roofs. J Anim Ecol. https://doi.org/10.1111/ 1365-2656.12648

Brenneisen S (2003) Ökologisches Ausgleichspotenzial von extensiven Dachbegrünungen-Bedeutung für den Arten-und Naturschutz und die Stadtentwicklungsplanung. University of Basel, Dissertation

Brenneisen S (2006) Space for urban wildlife: designing green roofs as habitats in Switzerland. Urban Habitats 4:27-36

Brenneisen S (2015) Begrünte Flachdächer, Norm SIA 312. Anthos 3: $16-18$

Brenneisen S, Hänggi A (2006) Begrünte Dächer-ökofaunistische Charakterisierung eines neuen Habitat typs in Siedlungsgebieten anhand eines Vergleichs der Spinnenfauna von Dachbegrünungen mit naturschutzrelevanten Bahnarealen in Basel (Schweiz). Mitt Natur forsch Ges Basel 9:99-122

Callot H (2016) Liste de référence des Coléoptères d'Alsace. Société Alsacienne d'Entomologie. www.societe-alsacienne-entomologie.fr Accessed 12 Nov 2016

Chittaro Y, Marggi W (2016) Bilan d'une année de recherches ciblées de Carabiques en Suisse: découverte de Notiophilus quadripunctatus Dejean, 1826 et autres captures remarquables (Coleoptera, Carabidae). Entomologische Blätter und Coleoptera 112:107-120

Colla SR, Willis E, Packer L (2009) Can green roofs provide habitat for urban bees (hymenoptera: Apidae)? Cities Environ 2:1-4

Czechowski W (1981) Carabids (Coleoptera, Carabidae) of Warsaw and Mazovia. Memorabilia Zoologica 34:119-144

Darius J, Drepper J (1983) Ökologische Untersuchungen auf bewachsenen Kiesdächern in West-Berlin. Diplomarbeit, Freie Universität Berlin

Deichsel R (2006) Species change in an urban setting - ground and rove beetles (Coleoptera: Carabidae and Staphylinidae) in berlin. Urban Ecosyst 9:161-178

Duelli P, Obrist MK, Schmatz DR (1999) Biodiversity evaluation in agricultural landscapes: above-ground insects. Agric Ecosyst Environ $74: 33-64$

Gerner M (2015) Green roof biodiversity assessment: eco-faunistical investigation of green roofs by monitoring beetle species (Coleoptera). Zurich University of Applied Sciences, Master's dissertation

Getter KL, Rowe DB (2006) The role of extensive green roofs in sustainable development. Hortscience 41:1276-1285

Gonsalves SM (2016) Green roofs and urban biodiversity: their role as invertebrate habitat and the effect of design on beetle community. Portland State University, Dissertation

Gonseth Y, Wohlgemuth T, Sansonnens B, Buttler A (2001) Les régions biogéographiques de la Suisse-explications et division standard. Cahiers de l'Environnement 137:1-48

Greenslade PJM (1964) Pitfall trapping as a method for studying populations of Carabidae (Coleoptera). J Anim Ecol 33:301-310
Hirschfelder A, Zucchi H (1992) Zur Besiedlung begrünter Gebäudedächer durch Carabiden - ein Beitrag zur Stadtökologie. Z Ökol Nat schutz 1:59-66

Homburg K, Homburg N, Schaefer F, Schuldt A, Assmann T (2014) Carabids.Org-a dynamic online database of ground beetle species traits (Coleoptera, Carabidae). Insect Conserv Divers 7:195-205

Huber C, Marggi W (2005) Raumbedeutsamkeit und Schutzverantwortung am Beispiel der Laufkafer der Schweiz (Coleoptera, Carabidae) mit Erganzungen zur Roten Liste. Mitt Schweiz Entomol Ges 78:375-397

Kadas G (2006) Rare invertebrates colonizing green roofs in London. Urban habitats 4:66-86

Kadas G (2010) Green roofs and biodiversity: can green roofs provide habitat for invertebrates in an urban environment? Lap Lambert Academic, Saarbrücken

Kaupp A, Brenneisen S, Klausnitzer B, Nagel P (2004) Eco-faunistic characteristics of the beetle fauna of vegetated roofs (Insecta: Coleoptera). Entomologische Blätter für Biologie und Systematik der Käfer 100:47-83

Klausnitzer B (1988) Arthropodenfauna auf einem Kiesdach im Stadtzentrum von Leipzig. Entomologische Nachrichten und Berichte 32:211-215

Klausnitzer B, Richter K, Pfüller R (1980) Ökofaunistische Untersuchungen auf einem Hausdach im Stadtzentrum von Leipzig. Wiss Z Karl-Marx-Univ Leipzig Math-Naturwiss 29:629638

Kotze DJ, Brandmayr P, Casale A, Dauffy-Richard E, Dekoninck W, Koivula MJ, Lövei GL, Mossakowski D, Noordijk J, Paarmann W et al (2011) Forty years of carabid beetle research in Europe-from taxonomy, biology, ecology and population studies to bioindication, habitat assessment and conservation. ZooKeys 100:55-148

Kromp B (1999) Carabid beetles in sustainable agriculture: a review on pest control efficacy, cultivation impacts and enhancement. Agric Ecosyst Environ 74:187-228

Lachat T (2010) Evolution de la biodiversité en Suisse depuis 1900: avons-nous touché le fond? Haupt Verlag AG, Bern

Löbl I, Smetana A (2003) Catalogue of Palaearctic Coleoptera. Apollo Books, Stenstrup 1

Lövei GL, Sunderland KD (1996) Ecology and behavior of ground beetles (Coleoptera: Carabidae). Annu Rev Entomol 41:231-256

Luka H, Marggi W, Huber C, Gonseth Y, Nagel P (2009) Fauna Helvetia Carabidae Ecology-Atlas. CSCF \& SEG, Neuchâtel

MacIvor JS, Lundholm J (2011) Insect species composition and diversity on intensive green roofs and adjacent level-ground habitats. Urban Ecosyst 14:225-241

Marggi W (1992) Faunistik der Sandlaufkäfer und Laufkäfer der Schweiz. Doc Faun Helv 13:1-477

Marggi W (1994) Rote Liste der gefährdeten Laufkäfer und Sandlaufkäfer der Schweiz. In: Rote Liste der gefährdeten Tierarten in der Schweiz (ed.) Bundesamt für Umwelt W. U. L. Eidgenössische Drucksachen und Materialzentrale (EDMZ), Bern, pp 55-59

Mecke R (1996) Die Fauna begrünter Dächer: ökologische Untersuchung verschiedener Dachflächen im Hamburger Stadtgebiet. University of Hamburg, Diploma dissertation

Meierhofer D (2013) Ground beetles (Carabidae) on San Francisco green roofs. CitiesAlive: 11th Annual Green Roof and Wall Conference. Green Roofs for Healthy Cities, San Francisco

Müller D (1988) Untersuchung von Extensivbegrünungen (Grasdächern) unter besonderer Berücksichtigung von Vegetation und Fauna. University of Essen, Diploma dissertation

Niachou A, Papakonstantinou K, Santamouris M, Tsangrassoulis A, Mihalakakou G (2001) Analysis of the green roof thermal properties and investigation of its energy performance. Energ Buildings 33: 719-729 
Niemelä J, Kotze DJ, Venn S, Penev L, Stoyanov I, Spence J, Hartley D, De Oca EM (2002) Carabid beetle assemblages (Coleoptera, Carabidae) across urban-rural gradients: an international comparison. Landsc Ecol 17:387-401

Oberndorfer E, Lundholm J, Bass B, Coffman RR, Doshi H, Dunnett N, Gaffin S, Köhler M, Liu KK, Rowe B (2007) Green roofs as urban ecosystems: ecological structures, functions, and services. Bioscience 57:823-833

Paill W, Holzer E (2004) Die Käferfauna (Coleoptera). In: Paill W (Red.) Naturdach Kraftwerk Friesach, Sukzessionsstudie. Forschung im Verbund, Schriftenreihe Band 87, Österreichische Elektrizitätswirtschaft-Aktiengesellschaft, Wien, pp 44-54

Pétremand G, Rochefort S (2016) La biodiversité entomologique des toitures végétalisées du canton de Genève. In: Rochefort $S$, Prunier P, Boivin P, Camponovo R, Consuegra D (eds) Rapport final du projet "Toitures végétalisées" (TVEG) dans l'agglomération genevoise. University of Applied Sciences and Arts of Western Switzerland, Hepia, Genève, pp 1-31
Rainio J, Niemelä J (2003) Ground beetles (Coleoptera: Carabidae) as bioindicators. Biodivers Conserv 12:487-506

Sattler T, Obrist MK, Duelli P, Moretti M (2011) Urban arthropod communities: added value or just a blend of surrounding biodiversity? Landsc Urban Plan 103:347-361

Tischler W (1949) Grundzüge der terrestrischen Tierökologie. SpringerVerlag, Berlin

Tonietto R, Fant J, Ascher J, Ellis K, Larkin D (2011) A comparison of bee communities of Chicago green roofs, parks and prairies. Landsc Urban Plan 103:102-108

Trautner J (1994) Die Laufkäfer Baden-Württembergs (Col., Carabidae s. lat.) - Übersicht zum Bearbeitungsstand sowie Aktualisierung von Checkliste und Roter Liste. Entomologische Nachrichten und Berichte 38:255-260

Venn SJ, Kotze DJ, Lassila T, Niemelä JK (2013) Urban dry meadows provide valuable habitat for granivorous and xerophylic carabid beetles. J Insect Conserv 17(4):747-764

Williams NS, Lundholm J, Scott MacIvor J (2014) Do green roofs help urban biodiversity conservation? J Appl Ecol 51:1643-1649 